\title{
THE DIFFICULTY OF AN OFFICIAL PERFORMING IN PUBLIC ADMINISTRATION WITH A FOCUS ON THE CZECH REPUBLIC
}

\author{
Lucie KAMRÁDOVÁ*, Marie SCISKALOVÁ(D* \\ The Institute of Public Administration and Regional Policy, Faculty in Public Policies in Opava, Silesian University, \\ Bezručovo námèstí 885/14, 746 01, Opava, Czech Republic \\ ${ }^{*}$ E-mails: lucie.kamradova@fvp.slu.cz, marie.sciskalova@fvp.slu.cz
}

\begin{abstract}
Purpose - the paper aims to present public administration as a managerial organisation which puts many requirements on its employees, respectively on officials in public administration. In today's globalised society, the boundaries between the public and private sectors are mutually intertwined. The difficulty of official's profession, both in terms of knowledge and psychology, is often wrongly criticised by civil society. The paper intends to point out the particular requirements and specify the risks carried by this profession.
\end{abstract}

Research methodology - the basic methods used are from the area of qualitative research. These are methods of analysis, induction and deduction. The method of description is used in the whole paper.

Findings - the result of the article is the identification of the principal risks and threats in the exercise of official activity.

Research limitations - the authors of the article see a certain limit that it is impossible to assess the demandingness of the official's performance in terms of the quantitative, as the structure of executive positions within the Czech Republic is problematic.

Practical implications - the identified risks can be beneficial for human resources management in public administration, to avoid frequent burnout in this profession.

Originality/Value - the paper presents the new perspective of a public servant.

Keywords: public administration, administrative body, official, law, duty, responsibility, management.

JEL Classification: M1, M140, H75, H76.

Conference topic: Contemporary Organizations Development Management.

\section{Introduction}

The current globalised society deals with a critical view of any profession connected to the state or public administration all the time. It is not a specifically new trend in society. It is more a factor that has appeared because of the unlimited amount of information and current information channels. The society has much more room to interchange experience concerning the work of public administration officials during the execution of state administration. The public media point out the errors and inadequacies that civil society encounters all the time. Unfortunately, it has been showing, in this regard, that negative news is conveyed much more often than the positive (more subjects can agree on what is wrong than what is right). The aim of this paper is, firstly, to show that administrative bodies act positively during the performance of state administration, which has become a modern and expertly runs an organisation. Secondly, it aims to show the difficulty of this profession from the academic, legal and social point of view.

This paper will refer to the above mentioned. In theoretical as well as in an empirical way on the example of a chosen country, in this case, the Czech Republic. The process of transformation of the public administration after the year 1989 has caused the disintegration of society on the level of the view of the activities of the state officials. It had also caused the loss of the memory that many of the laws and centralised bureaucratic administration is no longer valid. On the contrary, it has been replaced by new qualified employees with officer probations and high expertise, which is a prerequisite for the execution of a profession of this difficulty. At the same time, it creates room for individually thinking experts who keep and respect the rules of state law without the non-professional public considering it.

In general, it can be said that the public administration and its parts (bureaucratic apparatus) are a non-divisible element of the society of the 21 st century. The civil society has been influenced, limited and formed by many factors. Amongst those are political, cultural, social, demographic, communicative, technical, organisational, personal and 
other factors. The listing of these and other factors are important for the development of public administration. That is why the non-professional and professional public must consider them. Králík and Kutil (2013) note that one of the key conditions for the functioning of public administration is personal qualification and moral responsibility of all the participants of public administration, which is a professionally run organisation.

Paper uses basic research methods such as analysis, synthesis, induction and deduction. This methodological base follows up the main article goal, the position of public administration employees in the Czech Republic. Method of analysis deals with the division of the most complex parts; it is less complicated parts according to common or different parts. This method is primarily used in the introductory chapter, but it can also be found in the whole text. Synthesis is the opposite research method, and it is based on the combination of components or elements to form a connected whole. Soundness of this method is noticeable especially in the definition of the risks of the occupation of officials as well as in critical performance area. Both methods are followed by induction and deduction. Those methods were used in the area of secondary data analysis in the last chapter of the article. The most important method, crucial for the article is description method, a description of the phenomenon and it is qualities that are being studied. Without this method, the paper would lost its relevance (Hendl, 2005).

\section{Theoretical approaches}

At first, it is necessary, for this paper, to delineate the conceptual apparatus which is connected to the published paper. The theoretical delineation is important for authors of this paper because it will be used further on in the text. Public administration, state administration, local administration, centralisation and municipal officials are amongst these concepts.

The public administration can be characterised, for this paper, as an activity connected to providing public services. However, also the running of public affairs on the local and central level, and also securing matters and affairs in the public administration. However, Lacina says that the position and general characteristics of public administration is not an easy task. It depends on particular authors how they deal with the given problem. The views differ. According to Lacina the distinction between what is public and what is private administration is often unclear (Lacina, Kafka, Kolár̆, Mates, Starý, \& Svoboda, 2006). It can be said though that public administration is an activity connected to the existence of state and law.

State administration is, in general, the activity of state performed directly by the state or other institutions that were authorised by the state to do these activities (mostly ministries, state funds and local organs of the state administration).

Decentralised understanding of the management is characteristic for local administration. Its characteristic is based on the performance of state administration in the delegated authority of self-governing public-administrative corporations. In general, there is professional and local self-government. Among the positives of local self-government are primarily the performance of public affairs as close to the participants of the administrative procedures, the citizen, as possible.

The principles of centralisation and decentralisation are characteristic for the phenomenon of modernisation of particular public administrations in general. The essence of centralisation is performance, process, or the way of managing from one centre, the headquarters. It is a principle of transferring political power and responsibility from local, national and regional institutions and organs usually to the central organs of the state.

The concept of municipal offices is not connected to the subject of the paper and the management in public administration. However, it is related to the development of public administration in the area of the current Czech Republic. According to the authors of the paper, it might be appropriate to characterise this concept on a basic level. In general, municipal offices could be characterised as organs of the state administration of Czechoslovak state administration on the level of municipality, town, ward, district, region or country. They had their own formally elected organs and existed in the area of the current Czech Republic between 1945 and 1990.

\subsection{The development of a "democratic" public administration}

First of all, it is important to delineate the basic turning points of the stated issue, out of which the current public administration often proceeds. The main turning point of the creation of modern democratic public administration was the year 1989 and the fall of the communist regime in many countries. As well as in the current Czech Republic (until 1993 it had been a part of the Czechoslovak federal state). In this and the following years, the transformation of many states began towards the overall democratisation of the public administration. For the current Czech Republic (further on as CR) it meant mostly a dynamic development in the area of local administration. The municipal offices had been responsible for the local power until 1990 when they were replaced with the local self-government that had a long tradition (since 1849 until 1939 practically unchanged). Since the very beginning of the modern transformation, the local self-government also contained the execution of specific functions of state administration in delegated authority according to Act No. 367/1990 Coll. on Municipalities (municipality system). The district municipal offices were replaced with the district councils that had the character of the institutions of state administration. Regional offices were cancelled without a replacement. The whole reform of public administration in the Czech Republic can be divided 
into two phases. The implementation of higher local self-government units by Act No. 347/1997 Coll., was characteristic for the first phase. This act has only delineated the regions. Not their competences (14 regions were established, including the capital Prague) ${ }^{1}$. Act No. 129/2000 Coll. on Regions established those (Vomlela, 2014). The second phase of the reform focused mainly on the change of the order of organisation of state administration on the district level. The basis of that originated, on the one hand, from the de-concentrating and decentralisation character of the reforms of public administration. On the other hand, out of the need to change the existing system of local organisation of execution of state administration also based on the district level already in the year 1960. The result of the second phase of reforms was the establishment of municipalities with delegated municipal office and the establishment of municipalities with extensive power according to Act No. 314/2002 Coll.

\subsection{Modernisation of state administration}

As mentioned above, the public administration in the Czech Republic has undergone significant changes. Moreover, this was done in two phases. In general, the first phase meant the establishment of regions. This also meant the transfer of many competencies from the central state administration. The implementation of the second phase of the reforms of public administration also meant that the district offices were cancelled and competences moved to regions and municipalities. In 2002 the modernisation of central state administration began. The principle of rationalisation and effectiveness of central state administration were set as aims. Also the increase of horizontal coordination, support of using methods of expert management, modern technologies and the execution of state administration as service for citizens ensured by qualified officials. It is evident that modernisation is a gradual, long-term and never-ending process that adapt all the time to the turbulently changing society.

It is not only a Czech phenomenon. Many other states must deal with a critical view of the execution of state and public administration in general (e.g. United Kingdom of Great Britain and Northern Ireland, France, Germany etc.). There were several projects implemented in the area of the Czech Republic within the modernization, e.g.: Identification of the Functions of Central Administrative Offices, Modern Management Techniques in Central Administrative Offices, Implementation and Development of Quality in Central State Administration, Implementation of the Public Servants Act or the Development of Financial and Performance Management, (Ministry of the Interior Czech Republic, 2005).

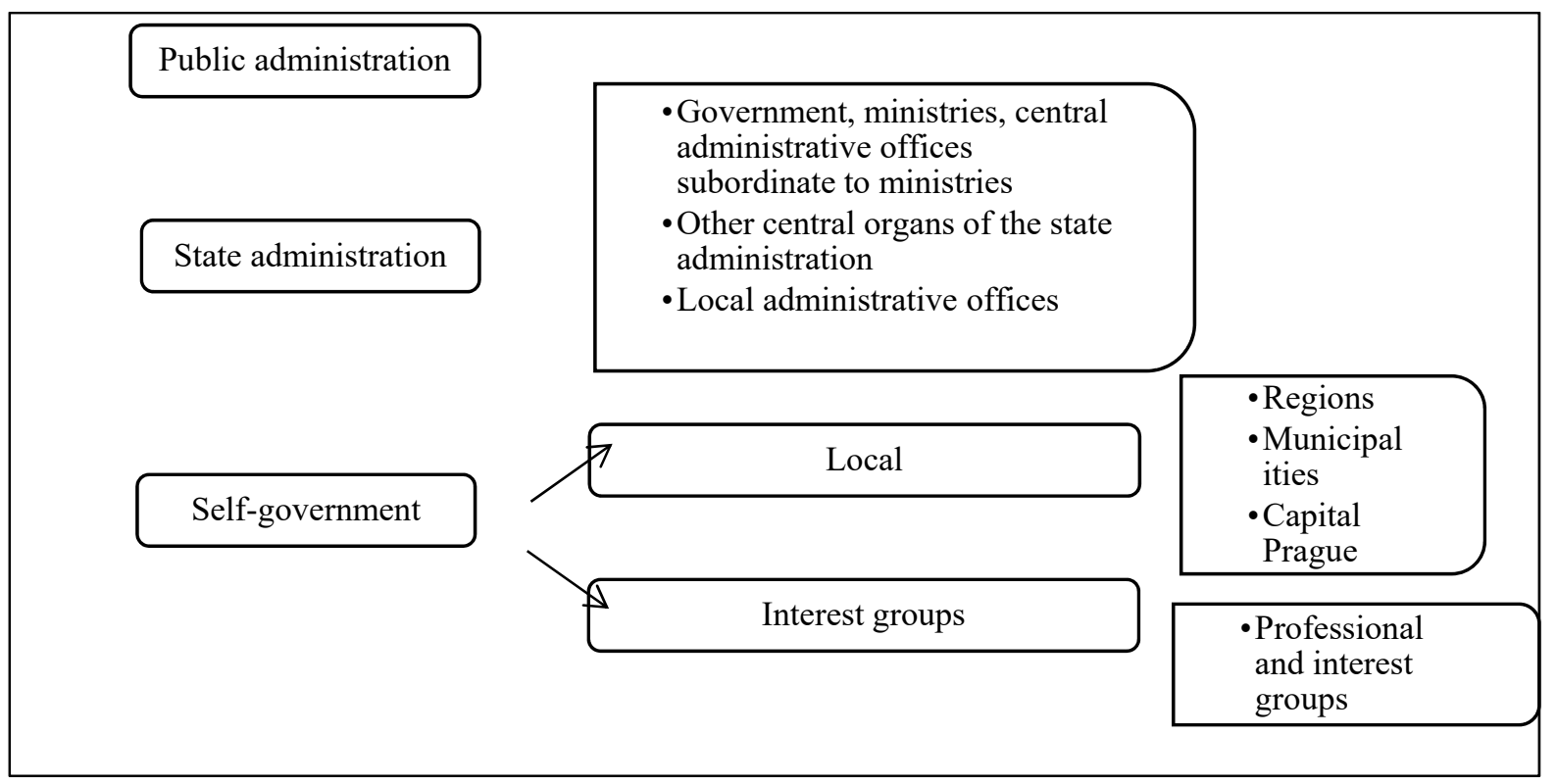

Figure 1. The structure of current public administration in the Czech Republic (source: created by authors)

\subsection{Management in public administration}

In the sixties and seventies, it used to be common in many western countries that the execution of the state administration was intransigently and adamantly connected with law. Only the gradual modernisation of particular public administrations brought forth different management theories which are, in their modified form, used until today. This step was a crucial change which, besides other things, has brought on the transformation of conceptions of professional education of elected officials of local self-government and workers of state administration, municipal and regional

\footnotetext{
${ }^{1}$ The number of regions and their seats was identical to the regions in the area of the current Czech Republic between 1949 and 1960.
} 

with a focus on the Czech Republic

offices. As already mentioned, the reforms of public administration have been taking place on the European continent since the sixties until today. Although in this case, Europe was lagging behind the United States and Canada where the management methods, in the form of so-called city management, were employed already in the thirties of the $20^{\text {th }}$ century.

What are the reasons that lead to the more significant implementation of managerial methods in current European public administrations? In general, we can say that it was a gradual process which affected the democratic part of Europe and then spread to the former, so-called, Eastern Bloc. During the last thirty years, there has been a certain diversion from the traditional understanding of the performance of administration activities which has been characterised as a continental system of public administration. This so-called nobility model simply stopped being relevant for the requirements of the $20^{\text {th }}$ century and the turbulently changing situation in society. This state has logically lead to the application of modern managerial attitudes which have been successfully applied in private which means business sector. One of the concepts that have appeared in connection to this situation could be considered the spreading of the concept of 'governance' which reflects the effort for democratization, decentralization and de-concentration of administrative activity and limiting of the concept of 'government' which mostly reflects the nobility understanding of the concept of administration (Lacina et al., 2006).

In general, the shift in the use of managerial but also marketing theories can be considered the broader development of processes known as the post-modernist managerial revolution. Room for development of these concepts was influenced by the loosening of traditional attitudes and organisational structures. Lacina, in his publication, characterises this period as a time of newly forming attitudes. At this time, the opinions, ideas and needs of consumers of the services and their ideas on the running of municipalities and regions started to be taken into consideration. Attitudes known in English as 'citizen participation' have been elaborated on this basis (Lacina et al., 2006). Among the leading causes of the reforms are:

- Limiting of budgetary financial means from the state budget connected with the public administration;

- The need for new international, inter-border and cross-border cooperation of public administration as a reaction on the changing political system in whole Europe;

- New challenges for the public administration in general;

- Reaction to the new problems that appear in civil society (the issue of natural environment, problematics of drugs, ageing of the population, equal rights for men and women).

The fact that modern technologies influence the current public administration to a great extent cannot be left out. It is an effort to make the performance of public administration easier and open it in this way to the citizen - client. As a reaction to this reality current European public administrations must quickly react for example to:

- Citizens were interested in high-quality and cheap services;

- The need for transparency in public administration;

- The effort for higher representation of women, less-privileged and socially and physically disabled social groups of citizens in elected functions in local self-governance.

It is obvious, from the above mentioned, that citizen participation is being emphasised in public administration. This is being proved by the fact that citizens - clients of the services provided by the public administration, have much more than in the past the possibility to influence the effectiveness, economy and efficiency of performed public administration. This fact is given by modern technologies and the world of media, which can smother us with unlimited information.

\subsection{New public management}

According to some authors, many European countries, currently members of the European Union, used the concept of New public management (further on as NPM) to reorganise their public administration. Followers of this concept usually characterise NPM as the key concept for the future. For example, Hughes says that 'the traditional model of administration is unmodern. It has been successfully replaced with a new model of management in public administration. The stated change represents the paradigmatic shift from the former bureaucratic model of the administration towards a market model of management, closely connected with the model successfully implemented in the public sector. Managerial reforms signify the transformation not only of the system of management in the public administration. However, also the relation between the market and the government, government and bureaucracy, bureaucracy and citizens.' (Hughes, 1998). In general, amongst the principles of NPM are these activities or realised reformative moves:

- Application of so-called 'three E' - efficiency, economy, effectiveness. This was mainly caused also by the limiting of budgets for the performance of public administration.

- The limiting of the powers of state administration.

- De-bureaucratization of public administration.

- Creation and improvement of the quality of monitoring system and evaluation of the activities of administrative offices and the public administration, as a whole, and of individual officials.

- The privatisation of a significant part of the services that the self-government provides to citizens. 
- The transfer of many activities and respond to the private-business subjects that provide, by contracts, the growing number of services for the citizens.

- Improvement of quality of personal resources management.

One of the crucial elements of the transformation of the whole system of the performance of public administration, as a reaction on NPM, was the launching of the continuous improvement of the quality of the modern understanding of professional education of elected representatives and workers at offices of public administration. This has been an important supposition for the more efficient and effective performance of administrative activities and at the same time a valued guarantee of their creativity. That is why, in the member states of the European Union on the level of state administration but also the level of local administration, systems of professional education were prepared. They were gradually put into practice. Moreover, they are still being improved until today. Professional education approached in this way has become one of the significant characteristics of the reforms of public administration in Central European countries. An article in chapter No. 3 deals closely with this fact.

\subsection{Total quality management}

On a theoretical and also practical level the principals of implementation of so-called total management are being discussed (further on as TQM). Similarly, as in the case of many concepts, also the TQM was tested first in the business sector, subsequently applied and modified for the public sector. We know from experience that it has been experimented with first in Japan and then in the USA and Canada. It has spread to the European systems in the nineties, respectively to the business sector. It can be said that it is quite a new model. The basis of this concept is the effort for the overall change of the behaviour of the organisation, all of its units and every worker. It is the elaboration of another managerial and marketing theories. They can be found in the business sector under the name marketing culture. The stated principle is considered to be suitable for management of public administration of the area with the primary focus on management of self-governing units. Although it has its specifics and aims, different than in the business sector. Lacina and colleagues state in their publication on education that 'the basis of the application of principles of TQM is in four key activities, mainly:

- The overall change of the relationship between elected officials, bureaucrats and citizens, seen in particular as clients of provided services. The ability of effective communication, efficient negotiating and empathy is a prerequisite from the elected officials of local self-government and officials of public administration. Polite behaviour of officials towards citizens, their active listening to their demands and needs. As well as readiness to operatively solve problems that the citizens come up with. These values are, in general, considered a self-evident condition of the work in public administration.

- A significant increase in the emphasis on quality of all the public services, which is often connected with the internal reorganisation of the administrative offices. In a way that they are more flexible and open to the requirements and needs of the citizens. It is, in a way, a realisation of the principles of marketing culture in the environment of the office of public administration.

- Considerable improvement of the ways of presentation of central offices of state administration, self-governing offices of municipalities and regions, their representatives, including in the state-wide, regional and local media. The emphasis put today on the presentation requires, amongst other things, preparation of specific methods of long-term communication of the representatives of public administration with the press, radio and television. That is one of the tasks of professional education.

- The developing of the best possible communication of elected representatives and officials with the citizens and by that asserting the principles of so-called citizen participation.

\section{The position of officials in public administration}

Peter F. Drucker says that people are the most important capital. It is undebatable that the concept comes from the private sector. Nevertheless, the strictly delineated border between private and public sector diminishes today (concepts of social responsibility, PPP etc.). In the professional-managerial dictionary the term human resources are characterised as one of the resources, respectively inputs into the productive processes. In the process, you can but do not have to differentiate an individual, group, organisational unit or the whole organisation (management). E.g. the portal BusinessInfo characterises the human resources as 'high quality, qualified and loyal workers that are the cornerstones of every successful organisation.

Nevertheless, it is necessary, within the stated characteristics of the concept of human resources, to point out the criticism of the concept which appears in connection to resources. Natural resources (such as wood, oil, iron ore) are also considered to be resources in the economy. In that connection, it may seem belittling to some authors. Bednár (2013) characterises officials as people who should know that 'their task is to represent the community, to protect its dignity and honour, to maintain the law and decide about the law. Also, at the same time, they should be aware that this was entrusted to their conscience'. Already the stated definition appeals to the issue of using human resources in the area of public administration. It also appeals to the difficulty of this profession. That is the reason why the issue of 

with a focus on the Czech Republic

human resources belongs to the elemental parts of administrative science and administrative policies that are generally considered to be parts of the problematics of public administration. The institute of public administration officer and its creation is closely connected to the assertion of state ideas of European states in the $18^{\text {th }}$ century which was constituted on the territorial principle. Certain 'feudal dependencies' were included in this relation of the ruler and their officials on this basis. For example, loyalty to the peculiarity of this power relationship, which used to be expressed by certain official ethos and law. It was an era in which bureaucracy was created as a particular profession. Today, in modern times, public administration is becoming more open and also transparent and more controllable. It starts to be understood more as a service to the public than just feudal administration with directive power (Zimek, 2010). The change of the role of public administration officer is connected to that. The change of the role of public administration official is connected to that. With the new role of officials (legitimate official person), the public administration is also connected with politics. It is a controversial relation. Naturally, public administration is the execution of the policies of state, municipality, region or another holder of public administration. That is the reason why the above-mentioned expression of loyalty still bears significance, even in the modern democratic state. However, also in the sense of neutral and loyal execution of state administration in the public interest. All that without taking into consideration the constitution of governing garniture. The order of such loyalty does not mean that the public administration officials should be somehow limited in the duties of their lifelong professional occupation, for unjustified privileges and inequality, for definite professional advance and the barrier to those stand behind the apparatus of the state. It points out that the effectivity of the clerical profession. Namely, it is the anonymity and isolation of the officials, keeping unnecessary official secrets, the solidarity of bureaucracy towards the outside which leads to non-transparency and irresponsibility of individual officials. E.g. corruption, but also delays in the processing of the affairs of citizens and other participants of the public administration. The role of public administration officials is firmly set in the law of the states in continental Europe. This is concretely embedded in the internal regulations that specify the position, duties and rights of public administration officials strictly. These regulations should also more closely describe the relations within a particular organisational unit or the whole organisational system, including the principles that the employees should abide by when dealing with other subjects or citizens. Among these principles are lawfulness, service to the public, ascertainment of the real state of things and also:

- Fulfilling tasks should be done with an understanding of the interests and needs of citizens.

- Incompetency should by in any case clarified, and the problematic issue sends to the corresponding organ.

- Citizens and other subjects should be given the possibility to look at particular law regulations and internal instructions if they ask for it or if it is necessary for their understanding.

- Participants of administrative procedures should be given information concerning their rights and duties. In other cases, citizens and other subjects should be given information and advice in cases they have a lawful interest in or that influence them directly.

These principles are, in modern and democratic countries, reflected in the law regulations and supported by ethical codes. There are mainly the acts of procedure law, administrative procedure code, administrative justice code and also legislation that provides the interested parties with the right to free access to information or that to introduce the institute of ombudsman (Sciskalová, 2014).

\subsection{The position of public administration officials in the Czech Republic}

In the Czech Republic, the fundamental law for characterisation of the profession of officials is the Act No. 312/2002 Coll., on officials of self-governing territorial units as subsequently amended (further on as officials). This act regulates the employment of the officials and their education. This act also characterises the profession of an official in the Czech Republic who is now considered to be an employee of a local self-governance office unit who participates on the execution of administrative activities. They are at the same time incorporated in the office of given local government unit. The act mentioned above does not relate to the employees categorised in organisational sectors of self-government unit, or to the employees in special organs or workers that do only so-called service work or supervise such work. It also does not apply to the members of elected organs of local self-government units. Neither to persons whose work relates to the given local self-government unit is determined by contract for work or contract for work activity even though these people might be doing or participating in administrative work. These labour-law relations follow Labour Code, not the Act on officials. An interesting fact is that the Act on officials determines the conditions for the beginning of the employment of the official.

A natural person with Czech citizenship can become an official. Also, a natural person who is a citizen of another country may become an official. Supposing they have permanent residence in the Czech Republic and are of eighteen years of age. They must also be legally competent, irreproachable, command of the official language and meets the requirements for performance of administrative work prescribed by the special legal norm. An interesting fact is the position of the officials with a focus on their duties, which is again adjusted by special legal adaptation of the mentioned act. Other duties of officials, except the above mentioned, include the requirement of keeping away from behaviour that would severely impact the credibility of the self-government unit (municipality, region). 

with a focus on the Czech Republic

The position of public administration officials does not relate only to the particular adjustments of conditions that are prescribed by the act for the beginning of employment. It also concerns other education which is obligatory for officials in the Czech Republic. The local self-government (municipality, region) arranges for education with accredited educational institutions. Every official must form a timetable for the improvement of their education. The local self-government unit is required to form this plan no later than one year since the beginning of the officials' employment. This plan must include education in the extent of 18 days, during the following 3 years. The officials must improve their education in particular areas on the entrance and continuous education and during the preparation and certification for special professional qualifications. This education is finished with a test (Act No. 312/2002 Coll., on officials of self-governing territorial units).

Another law that is connected with the profession of an official in the Czech Republic is the Act No. 234/2014 on State Service. This act concretely adjusts the employment of public administration officials who perform state administration in administrative offices, their service relation, rewards and management of employment issues. As well as in the case of the Act on Officials the enumeration of the duties that officials have to abide by is a part of the State Service Act. Among these duties is the duty to be loyal to the Czech Republic, to do their tasks personally, correctly and at the time, to improve their qualification, keep service discipline, keep the ethical rules of public administration officials etc. (Act No. 234/2014 on State Service).

\subsection{Requirements for public administration officials}

It is more than evident from the above mentioned that the requirements on the public administration officials often not only limit their labour-law relations but also reflect on the personal level. Among other things, they are limited in the area of another income and keeping loyalty. They are also prohibited from taking gifts which are considered to be common corruption etc. Also, the area of further education of officials of self-governing units or the public administration officials is a very difficult and complicated process. Many times this fact is forgotten, and the official is unjustly criticised subject of the state because they are the closest to the citizen. The requirements on employees in the public administration can be in general identified into following areas:

- Ethical requirements that are described in the act and recommendations of international institutions. Among these are the issue of corruption, corruptive behaviour, ethics and ethical codes.

- Psychological requirements which are given by the continuously changing legal environment, contact with clients, citizens and the need to balance personal and work life.

- Physical requirements which often stem from the psychologically demanding environment - often can lead to the burn-out syndrome.

- Social requirements that the official has towards the society and vice versa. The factor of negatively viewed bureaucratic environment often appears among these in general.

- Educational requirements which are given by the law, but also personal limits.

- Communicational limits which are given by the education of individual employees but also the improvement of the ability to communicate with clients.

The requirements mentioned above are, according to the authors, simply identification elements that can be modified accordingly to the needs of descriptive research. The issue of corruption is a very interesting element in general from the point of view of requirements (the authors categorise it in the group of ethical requirements). In general, hidden and dishonest behaviour is considered to be corruption. Authors see it similarly and taxonomically categorise it from different points of view (small, big, common, municipal etc.). The issue of corruption and corruptive behaviour has been targeted in research amongst officials that was done within the training courses for officials of local selfgoverning units in the Czech Republic to get the professional qualification, realised in 2016. Altogether one hundred and twenty officials have participated in the research. To the question, if an ethical code is taken into consideration, seventy per cent have responded yes. That is a high number in view of the public stance. One question concerning the relation of the ethical code and corruptive behaviour was especially interesting. Three quarters have responded that ethical code adjusts very well the behaviour and actions of officials of local self-governing units (meaning their workplace) in a way as to avoid corruption.

On the other hand, are one hundred and twenty respondents that have no information about this fact at all. A question for discussion appears. What is the problem then? Is it that the officials or the public are not informed well enough, or is it their superiors that are responsible in this way for not informing them enough? Nevertheless, it is a definite fact that the mentioned respondents know about the basic principles of corruptive behaviour. If asked what constitutes corruptive behaviour, ninety-nine per cent responded correctly. Concretely it was a question about the choice among given possibilities: taking a bunch of flowers, a bottle of alcohol, amount of money in cash and providing service in return. The respondents were very well acquainted with the fact that only taking a bunch of flowers is not a corruptive behaviour.

The difficulty of an official's performance is not given by the performance itself, meaning from the officer towards the client (citizen) but also from the client towards the officer. There is a significant number of aggressive clients that are not able to manage their emotions, and the officials are often the first to encounter this aggression. In general, 

with a focus on the Czech Republic

this phenomenon is called aggressive clients. However, public administration officials must be prepared even for this phenomenon. It is clear from the practice that this behaviour is nothing new and therefore work with these clients and managing of necessary principles are parts of further education of employees. It is an interesting fact that many offices already take these aggressive and negatively behaving clients into account. For example, the city council in York in England has published a booklet on the dealing with these clients from the point of view of officials (instruction in the booklet are mandatory) A part of the book is the instructions on behaviour towards an aggressive or problematic client. One of the recommendations for an official is to keep calm, keep smiling, use assertive methods and only in an extreme case is the official allowed to leave the counter (Grzywa, 2002).

\section{Current practice in the public administration sector}

Current public administrations, which include both the execution of public administration and self-government, form a sophisticated management system. Interconnection with legal matters poses no obstacle for modern society to ensure implementation of new management methods and apply findings from the private sector. When we leave out the organisational structuring, which has often been shaped by the traditions and possibilities of individual public administrations, we can generally state that all democratic public administrations have undergone a reform based on the principles of the so-called 3E. These have more or less included both NPM and TQM principles and marketing strategies. The modern society with its turbulent changes has, however, exercised pressure upon public administration institutions calling for the yet greater implementation of open-government principles towards the general public as well as towards employees in general.

For this reason, concepts created and developed over the years exclusively in the public sector have been used over the last decades. They are, for example, the CSR (Corporate Social Responsibility) Work-Life Balance concepts. The latter mention concept has seen much support in recent time, predominantly in the public administration sector.

The issue of responsible corporate organisations has become a global phenomenon of the modern age. This concept created first of all for the sake of the private sector which sees in public administration a responsible partner in the field of economic stability, environment protection and social development. What does it concretely mean, then, to become aware of one's corporate responsibility? A commitment for an organisation (public administration authority) to contribute to social, economic and environmental development of the society, namely beyond the extent required by the law. CSR poses a concept within which public administration authorities openly proclaim their share in the responsible running of the society and which comes from the presupposition that no public administration authority may only function within its economic relationships, but that it always has its impact on its environment (community, employees' social situation etc.). Various interest groups, in return, have their influence on the rate of success of a public administration authority. It is important at the same time that authorities should not understand their corporate responsibility as mere random activities, but that they exercise it as an integral part of all aspects of its activities. An actual responsibility of an authority or corporation towards the citizens, i. e. customers, employees, the environment or other subjects concerned constitutes the most natural philosophy of fair public service or business. So termed triple responsibility (economic, social and environmental) of authority may, for instance, demonstrate itself in increased transparency with an authority's decision making, increased competence, and a more active approach in resolving public administration issues (Pavlík, 2010).

The currently used approach of Work-Life Balance, which has been a subject of debate in many spheres, is currently essential for the public administration branch and its management. This approach strives to design the performance possibilities in public administration organisations in such a way for the official to be able to feel comfortable and return a responsible performance at work both in the direction inwards (superiors, fellow officials and the public administration office) and outwards (client, citizen). This field has been subject to very interesting research in the Czech Republic the outcomes of which need to be further present not only to show an example of good practice but also in order to promote a positive view of the public administration field. The outcomes of the mentioned research map the sphere of harmonising one's professional, personal and family life with a sample of selected central public administration bodies. It is the output of a sociological survey conducted at 11 ministries which participated in the project Služba šitá na míru (Service Tailor-Made) administered by the Office of the Public Defender of Rights. Anna Šabatová (Public Defender of Rights in the Czech Republic) states in the final report to this research project that "issues of harmonising family and professional life have rightly received a growing amount of attention in the Czech Republic. More and more space is given in the private, but also in the public sector to various instruments, measures and programmes which prevent us from having to face a choice of either devoting our time to family or our profession but enable us in various ways to combine them. Keeping a balanced position between these two crucial components of our lives is of fundamental importance both on the individual (private) level and from the employers' perspective as this sphere is closely connected with employees' feeling content and, therefore, with their loyalty, work efficiency and performance. Moreover, implementation of harmonising measures help to ensure equal opportunities of women and men and assert the right on equal treatment. It is usually women by whom the larger part of caring for the family is borne. As a result, women have to face becoming less involved in professional life and the ensuing economic impacts. Implementation of harmonising measures bring all-women and men - an equal possibility of a more balanced sharing 

with a focus on the Czech Republic

the duties of family care and flexibly combining their family and professional lives." (Šabatová, Hampl, Maříková, Uraníková, \& Kvasnicová, 2017). Among the most interesting outcomes there is the question directly concerning the employer, i. e. the ministry office. Both men and women state employees express their content with the way their direct superior shows an understanding for employees' needs regarding their personal and family life - maximum rating is given by half of them, about 8 in 10 of them express rather a favourable than unfavourable position. Considerable consent was also found for instance in the field of gender equality and in the field of following laws and legislation concerning state employees. Approximately a third of the respondents (about $70 \%$ ) expressed full agreement, $10 \%$ disagree. A little bit lower amount of favourable answers relate to the ministry's treating employees with respect, making no difference about position and origin, as well as to one's personal ability of harmonisation ("I can manage to..."). About $15 \%$ of employees expressed disagreement with these statements. About two-thirds of employees agreed that it was possible to achieve it at their workplace to harmonise one's working and family life and that it was possible to regard their office as friendly towards family and private life. The share of dissatisfied respondents amounted to $17 \%$ in such cases (Šabatová et al., 2017).

Despite the above mentioned, a risk and criticism of performance public administration officials still occur. Despite the requirements for them in many fields - not excluding their life-long education duties - the general public often views employees negatively, and it makes an influence on how the employee view themselves. A certain confidence crisis marks the current viewing of officials in the eyes of the general public. Countless media contributions concerning the execution of public administration are made in a rather hostile tone, and their impact projects itself into viewing the image of officials. "It is understandable that in market economy conditions journalistic practice is first of all concerned with publishing such mistakes and shortcomings which are extraordinary and bombastic and which can in a desirable way influence an increase in printed copies or people listening to the radio or watching TV." (Dytrt, Roudný, Skipala, \& Volejníková, 1997). Intensive paperwork, rise in the number of administrative actions, but also, for instance, the moral and working attitudes of officials are mentioned in this context. Vaněčková implies that shaping the views of the general public should follow to aims. First of them is consistent fulfilment of public administration activities as a public duty. The latter aim ought to seek the elimination of illegal action on the side of the public administration workers. The outlined aims are incorporated in the government's anti-corruption strategy, and they are fulfilled through three pillars which are prevention, transparency and recourse (Ministry of Interior of the Czech Republic, MVČR, 2008). The issue of viewing officials by the general public is not unambiguous, and a space for dialogue between the two parties involved is open. Despite all negative views and corruption affairs one still cannot ignore the fact that the performance of an official in public administration is, first of all, a duty to the general public which bears in itself a continuous need for education, self-discipline and respect, which many of us do not realise.

\section{Conclusions}

The paper aimed to present the performance of public administration with regards to an official working in this field. The paper wants to point at the fact that despite public administration is an organisation run in a managerial way, whose work is predominantly directed by legislation, one cannot ignore the fact that the human factor presents an indispensable part in the functioning of public administration. The conclusions made could be outlined in several points as follows:

- Democratic countries have experienced significant reforms in the last decades, practically since the 1960s.

- The public administration reforms were more or less based on principles of NPM and TQM.

- Modern public administration makes use of managerial and marketing concepts which originated predominantly in the private (business) sector and were eventually applied in the public sector.

- Legislation and other provisions approach the position of officials and employees in public administration.

- Employees in public administration are obliged to participate in further education; they are bound by special legal provisions

- Current public administration strives to create more quality working conditions based on harmonising professional and private lives of employees. It at the same time makes use of the new concept of opengovernment concerning the local community - application of the CSR concept.

- Negative as well as positive views of public administration employees' performance are to a certain extent also influenced by the media.

These points only form part of the whole issue concerning public administration and the entire system of employment in public administration. It depends on individual governments which position they adopt towards the issues and which strategy for ensuring a favourable view of the functioning of public administration they adopt. Each performance, however, involves certain risks which may emerge in connection with adopting the particular strategies. Employee-related risks may be divided into three primary areas:

- Social risk: Possible isolation of employees from society by strict legislation provisions and exclusion of citizens who are not bound by law in their employment from certain social activities.

- Mental risk: Higher risk of burn-out as a result of continually increasing professional requirements on employees and the amount of communication with clients. 

with a focus on the Czech Republic

- Economic risk: The disproportion between the number of duties and salary in the public sector often becomes the cause of employees migrating to the private sector.

It is apparent that the whole issue is more complicated than many citizens may view it at first sight. It is impossible to accurately delimit which public administration works well and what a perfect prototype of an official looks like. This is so because the whole system is based on the human factor, i. e. on people, who do not give constant performance despite having the same qualifications and means for exercising their duties. The authors of this paper aimed to enhance discussion in this field and to make possible recommendations for further research in this field, both practical and theoretical. Paper is based on the literature and other sources, such as legal norms, legislative documents of the legal order of the Czech Republic. From the theoretical perspective, the paper is also based on theoretical literature, and the sources from the Czech academic and professional environment in the context of phenomenon paper focuses on.

\section{References}

Bednář, V. (2013). Člověk není zdroj. [online]. In Firemní sociolog. Vedení a vztahy ve firmě. [cit 2019-02-10]. Retrieved from https://www.firemni-sociolog.cz/cz/clanky/219-clovek-neni-zdroj

Czech National Council. (1990). Act no. 1990/367/CSFR Coll., on Municipalities (municipality system). Retrieved from https://zakonyprolidi.cz/cs/1990-367/zneni-20000428\#redakce

Czech Parliament. (1997). Act no. 1997/347/CZ Coll., on the creation of higher territorial self-governing units. Retrieved from https://zakonyprolidi.cz/cs/1997-347

Czech Parliament. (2000). Act no. 2000/129/CZ Coll., on regions. Retrieved from https://zakonyprolidi.cz/cs/2000-129

Czech Parliament. (2002). Act no. 2002/314/CZ Coll., on establishment of municipalities with a delegated municipal authority and determination of municipalities with extended powers. Retrieved from https://www.zakonyprolidi.cz/cs/2002-314

Czech Parliament. (2002). Act no. 2002/312/CZ Coll., on officials of territorial self-governing units and amending certain other acts as subsequently amended. Retrieved from https://www.zakonyprolidi.cz/cs/2002-312

Czech Parliament. (2014). Act no. 2014/234/CZ Coll., on state service as subsequently amended. Retrieved from https://www.zakonyprolidi.cz/cs/2014-234

Dyrt, Z., Roudný, R., Skipal, J., \& Volejníková, J. (1997). Etika podnikání a veřejné správy. Praha, Czech Republic: VUSTE ENVIS.

Grzywa, M. (2002). Vzdělávání úředníkio je povinné. Retrieved from https://moderniobec.cz/vzdelavani-uredniku-je-povinne/

Hendl, J. (2005). Kvalitativní výzkum. Praha, Czech Republic: Portál.

Hughes, O. E. (1998). Public management and administration: An introduction. New York: St. Martin's Press.

Králík, J., \& Kútik, J. (2013). Kontrolný systém a jeho susystémy vo verejnej správe. Plzeň, Czech Republic: Aleš Čeněk.

Lacina, K., Kafka, M., Kolář, P., Mates, P., Starý, M., \& Svoboda, K. (2006). Vzorový program pro vzdělávání tajemniků obcí s rozšiřrenou působností. Praha, Czech Republic: Vysoká škola finanční a správní o.p.s.

Ministry of the Interior Czech Republic. (2005). Retrieved from https://www.mvcr.cz/clanek/rada-vlady-pro-informacni-spolecnost.aspx

Ministry of the Interior Czech Republic. (2008). Retrieved from https://www.mvcr.cz/webpm/clanek/zakladni-informace-o-postupu-ministerstva-vnitra-v-plneni-strategie-vlady-v-boji-proti-korupci.aspx.

Pavlík, I. (2010). Správni věda. Teorie veřejné správy. Praha, Czech Republic: Wolters Kluwer.

Sciskalová, M. (2014). Veřejná správa. Karviná, Czech Republic: Slezská univerzita v Opavě, Obchodně podnikatelská fakulta v Karviné.

Šabatová, A., Hampl, S., Maříková, H., Urbaníková, M., \& Kvasnicová, J. (2017). Harmonising one s professional, personal and family life at ministries in the Czech Republic. Retrieved from https://www.ochrance.cz/fileadmin/user_upload/ESO/1012017-DIS-JKV-vyzkumna_zprava.pdf.

Vomlela, L. (2014). Charakteristika regionální politické úrovně v Česku a Polsku v kontextu Moravskoslezského kraje a Slezského vojvodství. In L. Vomlela \& P. Hušek (Eds.). Regionálni politické elity v Moravskoslezském kraji a Slezském vojvodství v letech 2000-2012 (pp. 28-40). Opava, Czech Republic: Slezská univerzita v Opavě.

Zimek, J. (2010). Ústavnost a český ústavní vývoj. Brno, Czech Republic: Masarykova univerzita. 